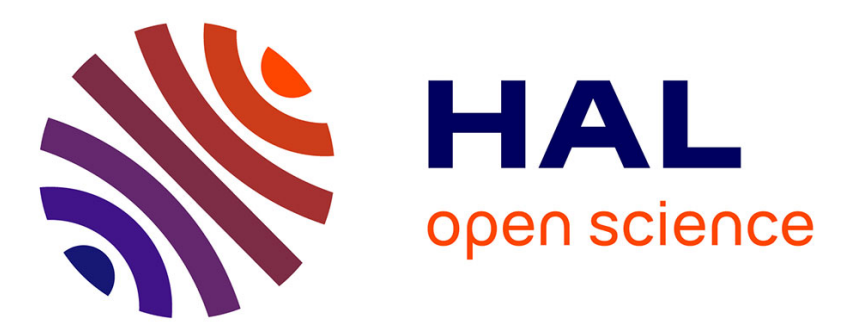

\title{
Why Might DRC Find Itself in a Complex Dilemma with the Conservative-Progressive Competition in the Post-COVID-19 World Politics?
}

Benjamin Mwadi Makengo, Joseph Mimbale

\section{- To cite this version:}

Benjamin Mwadi Makengo, Joseph Mimbale. Why Might DRC Find Itself in a Complex Dilemma with the Conservative-Progressive Competition in the Post-COVID-19 World Politics? Academia Letters, 2021, 10.20935/al3508 . halshs-03453473

\section{HAL Id: halshs-03453473 \\ https://shs.hal.science/halshs-03453473}

Submitted on 28 Nov 2021

HAL is a multi-disciplinary open access archive for the deposit and dissemination of scientific research documents, whether they are published or not. The documents may come from teaching and research institutions in France or abroad, or from public or private research centers.
L'archive ouverte pluridisciplinaire HAL, est destinée au dépôt et à la diffusion de documents scientifiques de niveau recherche, publiés ou non, émanant des établissements d'enseignement et de recherche français ou étrangers, des laboratoires publics ou privés. 


\title{
ACADEMIA $\mid$ Letters
}

\section{Why Might DRC Find Itself in a Complex Dilemma with the Conservative-Progressive Competition in the Post-COVID-19 World Politics?}

\author{
Benjamin Mwadi Makengo, University Of Kinshasa \\ Joseph Mimbale, University of Kinshasa
}

\begin{abstract}
This paper proposes to briefly explain why with the bullish trend of conservative-progressive competition in the post-COVID-19 world politics, DRC might find itself in a "complex dilemma". The latter is understood here as being a situation in which, when faced with a choice between two paths to follow, it appears not only difficult to go one way against the other, but also to manage to balance the two sides at the same time, by remaining in the middle without taking a position, by playing the neutrality of the third way without creating pronounced imbalances between the blocks of the conservatives and the progressives, represented here respectively by the United States and China. Our results show that this situation is more likely to catch $D R C$, because of its strategic character in the eyes of conservatives and progressives, its pronounced dependence on both China and the Western world, and its fragility due to problems of leadership and political governance. It is up to DRC to prepare and keep itself well, and learn from its past mistakes for its best survival.
\end{abstract}

Keywords: Complex Dilemma, Conservative-Progressive Competition, DRC's Best Survival, Post-COVID-19 World Politics 


\section{Introduction}

Since the beginning of the twenty-first century, a number of succession events on the international arena keeps shifting and making world politics become increasingly complex. Among these events, the $9 / 11$ attacks, the subprime crisis, the relative decline of Western power, the rise of China, and the growing resurgence of Russian power on the international stage cannot be overemphasized (Fukuyama, 2020; Makengo, 2021b; Makengo, 2021a; Makengo \& Omoyajowo, 2021). With the recent COVID-19 pandemic added to the list of these events, the increasing complexity and ongoing shifting of world politics continue to be of interest to various scholars. Pre-COVID-19 world politics is no longer equal to the COVID-19 era, nor will it be equal to the post-COVID-19 era. For COVID-19, as an event, has come to play the role of a gas pedal of other events on the international scene, reshaping geopolitics and public policy. Events that should happen over time, COVID-19 just accelerated them. The most important of these is the rise of the "conservative-progressive competition" to a higher level than before COVID-19. It is a competition between those who want to maintain their dominance, power and influence in the world, in this or that region, activity or field-the "conservatives", and those who push for change - the "progressives" - a competition of the older influences against the newer ones [the Build Back Better World (B3W) versus the Belt and Road Initiative (BRI) serves well as a concrete example] (Makengo \& Omoyajowo, 2021). Of course, this competition is well dominated respectively by US and China, both accompanied by their allies and/or relatives. It is visible in different corners of the world, states and areas, considered strategic by both - to mention only the areas of high technology, energy and digital, and the corners of the South China Sea, the Middle East.... (Petsinger, Jie, \& Crabtree, 2019). The Democratic Republic of Congo (DRC), a geological blessing, known for the different raw materials' reserves that abound in its territory, is certainly not an exception, it is also one of the states where this competition keeps rising and rising. It contains about $80 \%$ of world's reserves of coltan; around 60 to $70 \%$ of world's reserves of cobalt according to US Geological; $10 \%$ of world's copper reserves; $30 \%$ of global diamond reserves, including other minerals of all kinds such as: tin, nickel, zinc, germanium, uranium, manganese, gold, silver, oil, gas...(Makengo, 2020a). However, this "conservative-progressive competition that is projected to take in bullish direction in the post-COVID-19 world politics, [this last one] viewed as a more suspicious and uncertain, and a more competitive and clearly divided world, might well place DRC in a "complex dilemma. The latter alludes to a situation in which, for a choice in front of two paths to follow, it appears not only difficult to go from one side against another, but also to manage to balance both sides at the same time, staying right in the middle without taking a position, playing neutrality-to make the third path. Just because

Academia Letters, September 2021

(C)2021 by the authors - Open Access — Distributed under CC BY 4.0

Corresponding Author: Benjamin Mwadi Makengo, benjaminmwadi@yahoo.com

Citation: Mwadi Makengo, B., Mimbale, J. (2021). Why Might DRC Find Itself in a Complex Dilemma with the Conservative-Progressive Competition in the Post-COVID-19 World Politics? Academia Letters, Article 3508. https://doi .org/10.20935/AL3508. 
of the possible costs of one choice to another, the consequences that should follow the day after one's choice or decision. Thus, making a decision among these three options requires careful navigation, which also may ultimately require a big price to pay in the long run (Makengo \& Omoyajowo, 2021). The question here is; why might DRC find itself in this situation of a complex dilemma with this conservative-progressive competition in the post-COVID-19 world politics?

Based on the existing literature, many scholars are already projecting the paradigm of great power competition, a scenario that can be described as a new "U.S.-China Cold War," drawing insights on the case of the U.S.-U.S.S.R. Cold War (Christopher, 2020; Wenzhao \& Shengwei 2020; Gregory, 2011). Others have not taken into account that Xi Jinping's China differs from Stalin's USSR in terms of ideology, strategy, and economics [unlike the USSR, China is not really interested in ideological issues, nor by pronounced interference in the internal affairs of other states - it is committed to the famous principles of peaceful coexistence, but is rather interested in economic issues, despite the fact that its gross domestic product (GDP) is still ostensibly less than 80 percent of US's GDP] (Makengo, 2020d). Some recent studies indicate that following the increasing rise of this conservative-progressive competition, we are gradually entering a phase where each state will deliberately choose its side-either to be close to US or to be close to China [which would not be easy for many states with both strong relations with China and the Western world-US, again, to mention here only the case of DRC that this paper intends to focus on]. However, a widespread view suggests neutralism to a number of states - playing balance game with US and China-which would be a difficult task for many of the states for a number of the reasons, are seen as weak and fragile in the balancing game, including DRC. The most important observation here is that these existing trends have not analyzed in depth the cases of states on the basis of a number of the substantial and consubstantial reasons, do appear to be fragile and weak, which are found mainly on the African continent. States where not only the choice of one side against another does not seem to be easy for them, but also the game of neutralism, such is the case of the DRC, the giant with feet of clay in the center of the African continent. This is the gap that this article wants to fill, drawing the insight from DRC's case to trace the conception of the "complex dilemma".

Against this backdrop, following the strategic analysis approach, this paper intends to explain succinctly why with this bullish trend of conservative-progressive competition in the post-COVID-19 world politics-as projected above, DRC might find itself in a complex dilemma. To support our central point, we briefly advance four (4) basic arguments, namely: DRC's strategic character in the eyes of conservatives and progressives (i), DRC's dependence on China (ii), DRC's dependence on the Western world (iii) and DRC's leadership and political governance problems (iv).

Academia Letters, September 2021

C2021 by the authors - Open Access — Distributed under CC BY 4.0

Corresponding Author: Benjamin Mwadi Makengo, benjaminmwadi@yahoo.com

Citation: Mwadi Makengo, B., Mimbale, J. (2021). Why Might DRC Find Itself in a Complex Dilemma with the Conservative-Progressive Competition in the Post-COVID-19 World Politics? Academia Letters, Article 3508. https://doi.org/10.20935/AL3508. 


\section{DRC's Strategic Characteristics in the Eyes of Conservatives and Progressives}

There is no doubt that both China [as well as Russia] and the Western world see DRC in a purely strategic light. This ostensibly places it in the clutches of the engaged, rising and merciless duel for world leadership between progressives and conservatives. The reason for this is, of course, the race for control of the strategic resources that teem the Congolese territory (Mimbale, 2021). The world is hungry for these resources at a time when questions are being raised about the new global stakes of energy transition and digital technology - the market for electric vehicles and other electronic gadgets such as smartphones, computers, tablets, robotics, etc. Thus, humanity would like to move towards a new dependency-that of rare and strategic metals, namely: Cobalt, Coltan, Rare Earths..., raw materials that are becoming more and more essential for the realization of a green economy and an ecological society in perspective. A priority objective pursued by several global actors to date, including US and China as leading figures. The minerals that DRC possesses, especially its cobalt-in a near-absolute advantage, are once again at the heart of this competition (Makengo, 2020b). As Caspar Rawles has remarked: "There will be no electric vehicle industry without DRC's cobalt. (...) without the DRC, this rise in electric vehicles will not happen" [Despite the continuous relativizations about this remark] (Makengo, 2020b). Yet China alone controls about $80 \%$ of Congolese production [one of the main reasons of its broad dominance in battery and electric vehicle production] (Makengo, 2020b). The Western world-led by the US-is getting annoyed. It keeps pushing to try to make up for the large gap with China. Neither of these two blocs-conservative or progressive, is ready to give up and lose the duel for the control of DRC. They keep showing themselves to be ready for anything, giving each other low blows and pulling strongly from one side to the other for the control of the strategic, rare and necessary minerals in which DRC abounds. Thus, DRC finds itself like a gazelle in the mountains in the middle of two hungry tigers, at the slightest misstep, the costs and damage are likely to be great against its best survival.

\section{DRC's Dependence on China}

Living largely in the exploration and exploitation of its raw materials, DRC's economic structure is increasingly dominated by the mining sector (Makengo, 2020a). With almost no processing industries, its economy is destined to be extraverted [depending only on the outside]. Indeed, DRC's dependence on China stems from several factors, including (1) The volume of investment in the mining sector: China controls about half of the investment in DRC's

Academia Letters, September 2021

(C)2021 by the authors - Open Access — Distributed under CC BY 4.0

Corresponding Author: Benjamin Mwadi Makengo, benjaminmwadi@yahoo.com

Citation: Mwadi Makengo, B., Mimbale, J. (2021). Why Might DRC Find Itself in a Complex Dilemma with the Conservative-Progressive Competition in the Post-COVID-19 World Politics? Academia Letters, Article 3508. https://doi.org/10.20935/AL3508. 
mining sector. This pronounced influence of China [DRC's largest economic partner-state by state] (Makengo, 2020a), gained over the years in the DRC, was enacted through the 2008 "infrastructure for minerals" agreement, which granted mining rights to China in exchange for substantial investment in DRC infrastructure. (2) The volume of trade between the two countries: more than half of the DRC's exports go to China and its imports from China represent about 20\%. (3) The construction of economic and social infrastructure: since Joseph Kabila's regime, following the signing of the Sino-Congolese contract, most of the Congolese infrastructure [roads, bridges, hospitals, schools, etc.] has been provided by Chinese companies. (4) Promotion of social mobility, transfer of skills and aid: China receives hundreds of Congolese students and trainees every year for university and professional training, financed by Chinese government scholarships. The Confucius Institute in Kinshasa and the Association for the Sino-Congolese Friendship are also well established in DRC. Also, the latter continues to benefit from financial, material and human assistance from China, including the latest during this COVID-19's time (Makengo, 2020c). All of this suggests the damage and costs in the wake of a clear-cut choice in favor of the conservatives - the western world, and against China. This makes it so that even though the current DRC president Felix Tshisekedi, since his seizure of power after the highly contested elections of 2018, for fear of reprisals from the Western world, has still not set foot on the territory of the first economic partner of the country that he holds the command [despite his many official trips made to various countries around the world]. Also, he still does not stop collaborating with China [in spite of its increasingly complex relationship with the Western world], especially for fear of seeing the collapse of the country's economy after he has given his back to it completely (Makengo, 2021b) [which makes DRC the 45th country to join BRI in January 2021].

\section{DRC's Dependence on the Western World}

DRC, despite its economic dependence on China, remains integrated into the "Western capitalist system" through, among other things: history [colonial ties]. It is an open secret that since the era of the "independence of cataclysms" in Africa, DRC's politics has not ceased to be ostensibly influenced by the Western world [Lumumba's death, successive elections since $2006 \ldots$... From economic-financial point of view [international trade, investment and aid], and the strengthening of institutional governance and security, we are thinking here to the preponderant roles that IMF, WB, UN-following its mission for the stabilization of DRC, are playing in the political and economic DRC's life [to mention here only the IMF financing in favor of DRC during this COVID-19 era of about 1.52 billion USD]. Moreover, once at odds with the regime of Joseph Kabila, the West has, since the political changeover of 
2018, regained its large voice in DRC's destiny. President Tshisekedi has been able to benefit from the support of the Western world to put aside his "ex-partners of the alternation" - the Common Front for the Congo (FCC). Similarly, after breaking away from the FCC, President Tshisekedi government continues to receive significant support from US in its efforts to combat corruption and promote the democratic process, good governance, human rights, security and justice [strengthening the authority of the state], the fight against epidemics, stability and peace within the country and in the region, and the attraction of American investment [following the U.S.-Congolese strategic partnership] (US. B.A.A., 2020). It must be said that these factors combined, reinforce the structural dependence of the country on the Western world. From here, one can already almost well imagine the costs and damages that should occur in the aftermath of DRC's choice against the Western world and in favor of China-and especially, combining with the stakes that will occur with the upcoming elections of 2023.

\section{DRC's Leadership and Political Governance Problems}

Leadership is a fundamentally key element for the development of nations-all the more so as it allows for informed strategic choices to be made for the country, and consequently for political governance adapted to the state's realities. This is why, for the African continent to take off, rhetoric alone is not enough, good leadership and quality political governance are needed. However, DRC continues to be at the bottom of the ladder in the various lists of leadership and governance indices [in the recent report of T.I. (2020), DRC is ranked 170/180, following a score of 18/100. According to IIAG (2020), DRC ranks 49th in Africa for good governance, scoring 31.7\%]. Since the era of independence, the Congolese governors, with some exceptions, have continuously shown a lack of some major attributes of the highest importance of quality political leadership and governance: a true vision for DRC's best future; the willingness, competence and capacity to execute the vision; and finally, the resources and character to ensure the realization of the vision with sound judgment [sobriety of mind], integrity and fairness. This once again makes them weak, exposes them and puts them at the mercy of various whims and maneuvers of great powers. Under these conditions, they will not be absolutely capable of fighting fully for the national interest of the country and resisting the various costs and damages that may occur in the aftermath of one choice to another.

\section{Conclusion}

The results that this paper has achieved clearly demonstrate that the "conservative-progressive competition", in bullish trend during this COVID-19 period, will indeed dominate the inter-

Academia Letters, September 2021

(C)2021 by the authors - Open Access — Distributed under CC BY 4.0

Corresponding Author: Benjamin Mwadi Makengo, benjaminmwadi@yahoo.com

Citation: Mwadi Makengo, B., Mimbale, J. (2021). Why Might DRC Find Itself in a Complex Dilemma with the Conservative-Progressive Competition in the Post-COVID-19 World Politics? Academia Letters, Article 3508. https://doi.org/10.20935/AL3508. 
national relations of the post-COVID-19 world politics. The latter-projected as: a more suspicion and uncertainty, and a more competitive and clearly divided world, following the "conservative-progressive competition", is more likely to place DRC in a "complex dilemma". Just because of its strategic character in the eyes of conservatives and progressives, its pronounced dependence on both China and the Western world, and its fragility due to problems of leadership and political governance. It is up to DRC to prepare and keep itself well, and learn from its past mistakes for its best survival.

\section{References}

Christopher, L. (2020). Preventing the China-US Cold War from Turning Hot. Chinese Journal of International Politics. 1-44. doi.org/10.1093/CJIP/POAA012

Fukuyama, F. (2020). The Pandemic and Political Order, It Takes a State. Foreign Affairs.

Gregory, K. (2011). US and China need contact, not cold war. Nature. 1-2. doi.org/10.1038/474444A

Ibrahim Index of African Governance (IIAG). (2020). https://mo.ibrahim.foundation/iiag (accessed Sep. 05, 2021).

Makengo, B. (2021b) Conservative-Progressive Power Games, Mutual Jostling in Africa and Resilience of Sino-African Relations under COVID-19 Wind. Open Journal of Political Science, 11, 439-460. doi: 10.4236/ojps.2021.113030.

Makengo, B. M. \& Omoyajowo, K. (2021). Post-COVID-19 World Politics and ConservativeProgressive Competition: Why Africa Might Find Itself in a Complex Dilemma? Academia Letters, Article 3283. https://doi.org/10.20935/AL3283.

Makengo, B. M. (2020a). China's Increasing Engagement in Africa: Opportunity and Futurisk for DRC's Sustainable Development. International Journal of Management Sciences and Business Research, 5, 191-216. doi: 10.5281/zenodo.4933775

Makengo, B. M. (2020b). Competitive Globalization and Quest for Strategic Minerals: DRC's Cobalt at the Heart of New Global Stakes, towards the Resource's Trap? International Journal of Management Sciences and Business Research, 9, 51-75. doi: 10.5281/zenodo.4964775

Makengo, B. M. (2020c). COVID-19 et Jeux de puissance en Afrique : Les relations Sino-Africaines Peuvent-elles résister ? International Journal of Management Sciences and Business Research, 9, 113-129. doi: 10.5281/zenodo.4990657

Makengo, B. M. (2020d). Globalization and Power Strategies: A Look at the US-China Trade War. International Journal of Management Sciences and Business Research, 9, 117143. doi: 10.22459/CYRD.07.2018

Academia Letters, September 2021

C2021 by the authors - Open Access — Distributed under CC BY 4.0

Corresponding Author: Benjamin Mwadi Makengo, benjaminmwadi@yahoo.com

Citation: Mwadi Makengo, B., Mimbale, J. (2021). Why Might DRC Find Itself in a Complex Dilemma with the Conservative-Progressive Competition in the Post-COVID-19 World Politics? Academia Letters, Article 3508. https://doi.org/10.20935/AL3508. 
Makengo, B. M. (2021a). COVID-19's Impacts and the End of Globalization? Open Journal of Social Sciences, 9, 212-233. https://doi.org/10.4236/jss.2021.91015

Mimbale, J. (2021). "La RDC dans le tourbillon du duel sino-étas-unien?," Chine Magazine.

Petsinger, M. S., Jie, W. \& Crabtree, J. (2019). US-China Strategic Competition the Quest for Global Technological Leadership. Asia-Pacific Programme and the US and the Americas Programme. 1-43.

Transparency International (T.I.) (2020). https://www.transparency.org/en/cpi/2020/index/ nzl (accessed Sep. 05, 2021).

US Bureau of African Affairs (US. B.A.A.) (2020). U.S. Relations With Democratic Republic of the Congo. US Department of State. https://www.state.gov/u-s-relations-withdemocratic-republic-of-the-congo/ (accessed Sep. 05, 2021).

Wenzhao, T. \& Shengwei, X. (2020). The US factor in post-cold war China-Russia relations. International Politics. 1-23. doi.org/10.1057/S41311-020-00211-1 